\title{
EDITORIAL
}

\section{The willingness to risk failure}

\section{Advice to Early Career Investigators}

(c) The Author(s), under exclusive licence to the International Pediatric Research Foundation, Inc 2022, corrected publication 2022

Pediatric Research (2022) 92:1490-1491; https://doi.org/10.1038/ s41390-022-01938-8

Pediatric Research, or rather the Editors-in-Chief, have decided to publish a series of editorials entitled, Advice to Early Career Investigators. We encourage suggestions for topics but have generated a list of our own. Since this is a new venture, we decided that the first editorial should be on the willingness to risk failure. Success in academia requires this trait, as with every paper submitted, every grant applied for, is, for the author, a willingness to risk that rejection or triage decision. What do we mean by the willingness to risk failure? Perhaps Harold Shapiro said it best:

In 1990, Science, the official journal of the American Association for the Advancement of Science, published an editorial written by Harold T. Shapiro, the President of Princeton University, as part of his commencement speech of that year. ${ }^{1}$ We quote, "Let me focus for a moment on the willingness to take informed risks. The willingness to risk failure is an essential component of most successful initiatives. The unwillingness to face the risks of failureor an excessive zeal to avoid all risks-is, the end, an acceptance of mediocrity and an abdication of leadership. To use a sports metaphor, if you do not come to bat at all, or, when at bat, wait hopefully for a walk, you cannot hit a home run. At best, you can get to first base. Major leaguers can decide to play in the minor leagues, and they may have more hits and fewer failures there, but their impact on the game and on society would be very much diminished. The risk of failure is intrinsic to significant accomplishment. Even the great Babe Ruth struck out almost twice as often as he hit home runs. Successful change depends on experimentation with uncertain results. A willingness to occupy new ground always involves the risk of losing your footing along the way".

The criteria for what constitutes failure is actually a personal choice. Each individual decides when they have met their criteria for failure. Some common examples of events that are frequently interpreted as failures are hypotheses for which the null hypothesis is proven, experiments that do not give the expected result, rejected manuscripts, triaged grant applications, and not being offered a sought-after job. Therefore, every time someone proposes new hypotheses, conducts new experiments, submits a paper or a grant, gets behind the podium to deliver a seminar or presentation, or applies for a new job or position, they are risking failure. Why risk failure? Because it's impossible to move research forward, get published, win a grant, inform the world about one's research, or get a new job without risking failure.

One might ask, what are the benefits of failing? Plenty! As Thomas Edison put it, "I have not failed 10,000 times-I've successfully found 10,000 ways that will not work"2 ${ }^{\prime 2}$ Experiments that fail may be telling one something, such as look in a different direction. As a former mentor of mine, Vance Lemmon, Ph.D., once quoted, "The truth will set you free". And as Gloria Steinem modified it, "The truth will set you free, but first it will piss you off!" ${ }^{3}$ How often is the null hypothesis proved? J.K. Rowling in her commencement speech to the Harvard University graduating class of $2008^{4}$ listed several benefits to failing: "So why do I talk about the benefits of failure? Simply because failure meant a stripping away of the inessential. I stopped pretending to myself that I was anything other than what I was and began to direct all my energy into finishing the only work that mattered to me. Had I really succeeded at anything else, I might never have found the determination to succeed in the one arena I believed I truly belonged. I was set free, because my greatest fear had been realized and I was still alive, and I still had a daughter whom I adored, and I had an old typewriter and a big idea. And so rock bottom became the solid foundation on which I rebuilt my life". Overcoming failure, which can't happen without failing first, gives one inner security, self-knowledge, determination and selfdiscipline, and security in one's ability to survive.

Several benefits to failure occur as part of the characteristics of failure. ${ }^{5}$ Of the 10 characteristics of failure, listed on this website, 5 of them are beneficial: opportunity, learning, information, stimulation, and fun! In his paper, Hillson declares that "Only when we know how to fail successfully can we become successful failures" ${ }^{\prime \prime}$. (https://www.pmi.org/learning/library/successful-failure6813). He proposes a cycle of failures and successes which evolves over time as we each get more comfortable with failing (Fig. 1).

When should one be willing to risk failure? This is the subject of the Serenity Prayer: "God grant me the serenity to accept the things I cannot change; The courage to change the things that I can; And the wisdom to know the difference" ${ }^{\prime \prime}$. One can only gain that wisdom with successive failures. For example, a first grant application may be brilliant, imaginative, ground-breaking but because it moves too far from the beaten path, be triaged. One would learn from this experience that proposals, at least to the National Institutes of Health (NIH), need to be firmly grounded and that high-risk proposals need a different funding mechanism. One would not simply revise the triaged grant and expect success.

Even Nobel laureates have failures. Consider Jennifer Doudna, the winner of the 2020 Nobel Prize for her discovery of CRISPR, a gene-editing tool. In her biography, The Code Breaker ${ }^{7}$, in January 2009 , she made a decision to move her lab from academia at the University of California Berkeley to a business, Genentech in order to develop more translational aspects of her discovery. Quickly feeling out of place within two months, she returned to Berkeley. Some would consider this a failure considering the time and effort used to pack up a lab and move it, not once, but twice. However, from this mis-step the book states, "she became more aware of 


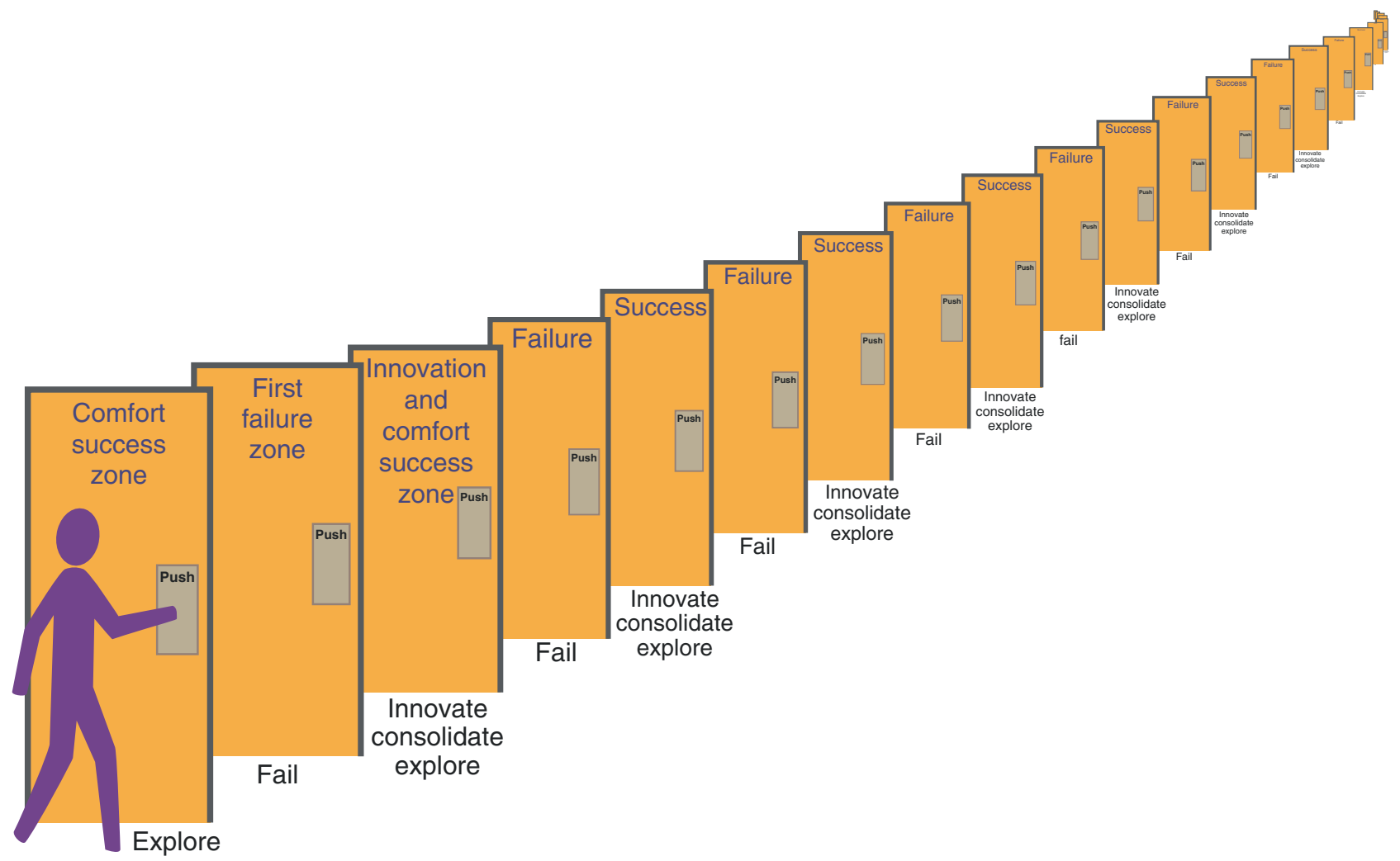

Fig. 1 The cycle of failures and successes. When striving for a life of success, one must recognize that this implies a life of failure also! We usually start in a Comfort Success Zone (CSZ), exploring all areas without entering the next room, that of the First Failure Zone. If instead of returning to the CSZ, we push and push until we push through the next door into that of the Innovation Success Zone, we learn new ways of succeeding and performing. As we innovate, consolidate and explore that zone it becomes a new CSZ from which we can push into a new failure zone, as we explore that zone, we can push into a new Success zone where we can once again innovate, consolidate and explore. These actions lead to a neverending succession of failures followed by successes (adapted from Hillson ${ }^{5}$ ).

her passions and skills - and also her weaknesses". Sound like she gained from the benefits of failure?

In summary, we encourage everyone to be willing to risk failure. They are great benefits to be had, and great scientific discoveries to be made, but only by a succession of both failures and successes.

Cynthia F. Bearer ${ }^{1 凶}$ and Eleanor J. Molloy ${ }^{1}$ ${ }^{1}$ Pediatric Research, https://www.nature.com/pr/. 凶email: Cynthia.Bearer@UHhospitals.org

\section{REFERENCES}

1. Shapiro, H. T. The willingness to risk failure. Science 250, 609 (1990).

2. https://www.smithsonianmag.com/innovation/7-epic-fails-brought-to-you-by-thegenius-mind-of-thomas-edison-180947786/.

3. Steinem, G. The Truth Will Set You Free, But First It Will Piss You Off! Thoughts ON Life, Love, and Rebellion (Random House, NY, 2019).

4. Rowling, J. K. The fringe benefits of failure, and the importance of imagination. The Harvard Gazette (2008) (youtube.com/watch?v=uibfDuPJEu).
5. Hillson, D. How to be a successful failure. In Paper Presented at PMI ${ }^{\circledR}$ Global Congress 2010 EMEA, Milan, Italy (Project Management Institute, Newtown Square, PA, 2010).

6. Shapiro, F. R. Who wrote the serenity prayer? The Chronicle of Higher Education (April, 2014).

7. Isaacson W. The Code Breaker: Jennifer Doudna, Gene Editing, and the Future of the Human Race. 560 (Simon \& Schuster, 2021).

\section{COMPETING INTERESTS}

The authors have no competing interests.

\section{ADDITIONAL INFORMATION}

Correspondence and requests for materials should be addressed to Cynthia F. Bearer.

Reprints and permission information is available at http://www.nature.com/reprints

Publisher's note Springer Nature remains neutral with regard to jurisdictional claims in published maps and institutional affiliations. 